\title{
Ecology-Based Sustainable Transportation System Development in Surabaya: Models and Strategies.
}

\author{
${ }^{1 \text { st }}$ Meirinawati ${ }^{1},{ }^{2 n d}$ Tjitjik Rahaju ${ }^{2},{ }^{3 r d}$ Galih W. Pradana ${ }^{3}$ \\ (meirinawati@unesa.ac.id ${ }^{1}$, tjitjikrahaju@unesa.ac.id ${ }^{2}$, galihpradana@unesa.ac.id ${ }^{3}$ )
}

Department of Public Administration Faculty of Social Science and Law Universitas Negeri Surabaya, Surabaya Indonesia ${ }^{1}$, Department of Public Administration Faculty of Social Science and Law Universitas Negeri Surabaya, Surabaya Indonesia ${ }^{2}$, Department of Public Administration Faculty of Social Science and Law Universitas Negeri Surabaya, Surabaya Indonesia ${ }^{3}$.

\begin{abstract}
Surabaya, as a metropolitan city, has a population of around 3 million. The city, which is part of the northern route of the island of Java, has become the current urbanization of Indonesian society. The high population density and high economic activity cause severe congestion problems in Surabaya. Besides, the number of private vehicle users has also increased, alleged to have triggered congestion in Surabaya city. Apart from causing congestion, it can also reduce the quality of life, such as human health and social impacts on the environment. The results from this study show that there are several models and strategies in the development of an ecologically-based sustainable transportation system in Surabaya, one of which is the Suroboyo bus. The suroboyo bus payment policy that uses plastic bottle waste has become an attraction for the community to make the Suroboya bus alternative transportation to replace private vehicles.
\end{abstract}

Keywords: Sustainable, Transportation System, Ecology

\section{Introduction}

In recent decades, the world has been urbanizing rapidly. In 1950, only 30 percent of the world's population lived in urban areas, a proportion that grew to 55 percent by 2018 [1]. Therefore, the traffic area appears to be the sticking point when organizing further urbanization. This, in turn, calls for a practical and almost failure-free planning strategy covering all stakeholders and their respective data needs [2]. Limited urban space is not only used for private transport, but also for delivery and pickup as well as for parking, for loading and unloading, and waiting [3]. The public and freight transportation system involves various human activities. Therefore the inclusion of the social sustainability dimension is required [4]. Transport must be brought closer to both the departure door, and the arrival door, and be able to operate in a more continuous manner and at a constant rate of speed [5].

Transportation design, planning, evaluation, and demand prediction are the starting points for the sustainable development of urban transportation [6]. Globally, transport policies have struggled to reduce car dependence [7]. To help transportation systems become environmentally bearable, economically viable, socially equitable, and thus tenable in all respects, it is important to quantify the sustainability of transportation systems [8]. The ongoing global urbanization trend, in combination with the ongoing 'objectification' trend, calls for a better understanding 
of management inside the type of project ecology [9]. Urban infrastructure systems (UIS) can be defined as the framework that connects and integrates the flows of capital (social, cultural, financial, natural, technological, and human) in the context of urban systems [10].

Surabaya is the capital of East Java Province, the second-largest city after Jakarta. With approximately $3,158,943$ people [11], Surabaya is a metropolitan city with a rich diversity in it. Besides, Surabaya is currently the center of trade, business, and education in Indonesia. Together with Lamongan, Gresik, Bangkalan, Sidoarjo, Mojokerto, and Jombang, these cities form a unit called the Kertosusila Gate. This causes Surabaya to become a national route so that many residents urbanize to the Surabaya City. As a result of urbanization and the development of Surabaya in various fields, it causes various problems in Surabaya as a big city, such as congestion, high crime, clean water crisis, limited residential land, air pollution, flooding, and so on.

The problems in Surabaya are now increasingly complex. High population density causes a clean water crisis so that the need for clean water in Surabaya is still insufficient. Residential land is limited because it has to share with industrial land so often when the rainy season arrives, Surabaya is always a regular customer of flooding every year. The problem that has never been resolved is the problem of congestion that occurs at several points on the highway.

The high rate of economic growth in urban areas has invited a high flow of urbanization because, for many people, it can provide vast employment opportunities. This leads to an increase in population growth rates and urbanization of workers in the city. Meanwhile, the surrounding buffer zones such as Gresik, Sidoarjo, Lamongan, and Mojokerto also have an impact due to high mobility. The level of urbanization has implications for increasing population density, which directly or indirectly reduces the competitiveness of regional Transportation [12]. Various economic drivers such as the center of trade, business, education, and the number of property developments, have made Surabaya a metropolitan city with a congestion rate of $16 \%$ and a long-running time when traffic is around 37 hours/year [13] and coupled with the growth in the consumption of private vehicles in Surabaya which reached an average of $7.63 \%$ for cars and $10.17 \%$ for motorbikes (data compiled from the East Java Regional Revenue Service, 2015 in the period 2010-2014). The increasing use of private vehicles has increased the quality of life, especially in urban centers, congestion, environmental pollution, both sound, and air. The volume of waste produced in Surabaya City increased in 2011 by 9,677.83 m3 / day, and in 2015, it was 9,475.21 m3 / day, in line with the development of the city of Surabaya. The area of public green open spaces in the city of Surabaya until 2015 reached 20.74 percent of the total area of the city of Surabaya or 6,853.09 hectares, which includes green open spaces for tombs, green open spaces for fields, green open spaces for ponds/reservoirs. Green open space from the handover of public facilities and social facilities, Green Open Space for protected areas, Green Open Space for urban forests, Green Open Space for parks, and green paths.

Environmental pollution dramatically impacts health and ecological investment in Surabaya. This must be a severe concern of the Surabaya city government in providing a comfortable and healthy area based on ecology, solid waste management, and optimization of Green Open Space management to be the primary efforts to improve environmental quality. In the concept of sustainable development to create a balanced life physically, ecologically, and socially for city residents, Green Open Spaces, especially Green Public Open Spaces in urban areas, is needed. The low quality of the environment and the provision of open public spaces psychologically can cause the mental condition and social quality of urban communities to become worse and more depressed. There is a growing awareness of the adverse health effects associated with various exposures and transportation practices, especially in Surabaya. According to research conducted in Barcelona, the health impacts of the transportation system 
include air pollution, noise, heat, green spaces, and physical activity states that $20 \%$ of premature deaths can be prevented by changing current urban transport practices [14]. Thus, transportation plays a central role in urban development in the economic and social fields, layout, and spatial planning [15]. A sustainable transportation system is more easily realized in a transportation system based on public transportation than a system based on the use of private vehicles. A sustainable transportation system is a new order for the transportation system in the current era of globalization. Transportation issues become problems that require attention and study from various perspectives of science [16].

In the beginning, government officials want to implement a sustainable transportation system. The government's efforts in realizing a sustainable transportation system are manifested by the existence of a new service from the Surabaya City Transportation Agency, namely the Surabaya Bus. To realize an environmentally friendly mass transportation system, people can pay for plastic waste. With this system, it can help the government in reducing waste in the community. In reducing air pollution, the government is pushing the construction of Surabaya parks. So that the gardens that are built can neutralize transportation pollution in Surabaya. Various government efforts have been made by making strategies to create a sustainable life. The development of the increasingly global environment, and increasingly complex transportation problems, require solutions by considering environmental factors. So that the government's role must be able to respond and accommodate all interests in the framework of democracy. Based on the above background, the authors are interested in examining these problems, with the title "Ecology-Based Sustainable Transportation System Development in Surabaya: Models and Strategies."

\section{Methodology}

This research uses literature study research such as related scientific journals, online media, and official news portals. The main data sources are also supported by qualified library sources. This research was conducted to determine the Strategy for Ecological-Based Sustainable Transportation Systems in Surabaya, especially in the case of Surabaya Bus transportation carried out by the Surabaya City Government.

\section{Finding and Discussion}

\section{Suroboyo Bus as an Ecology-Based Sustainable Transportation}

Suroboyo Bus is a rapid transit bus transportation owned by Surabaya City. This means of transportation launched by the Mayor of Surabaya, Tri Risma Harini, on April 7, 2018, in the Siola City Surabaya building. Each Surabaya Bus fleet can accommodate as many as 67 people. Suroboyo Bus operates from 06.00-22.00 WIB. The bus has a width of $2.4 \mathrm{~m}$ and $12 \mathrm{~m}$ with different color seat facilities with predetermined specifications, namely red seats for female passengers and orange seats for man passengers. The difference in seats is intended to minimize the occurrence of acts of sexual harassment. Sustainable transportation is transportation that pays attention to the rights of every passenger. The city government of Surabaya, in providing services, must prioritize a sense of comfort and safety for public service lovers. Besides, other facilities such as CCTV and bus doors were equipped with sensors. Payment when riding this 
bus is for using plastic waste, which can reduce environmental problems and save the ecology in Surabaya.

Suroboyo Bus is one of the ways or efforts to achieve Environmentally Sustainable (sustainable transportation) developed by the OECD. EST emphasizes developing a vision for the desired future and clearly defined milestones. In contrast to the approach commonly applied in various cities, policymakers were only preoccupied with efforts to prevent detrimental development symptoms at that time, rather than working to achieve the stated goals.

The following is a map of the concept of sustainable transportation:

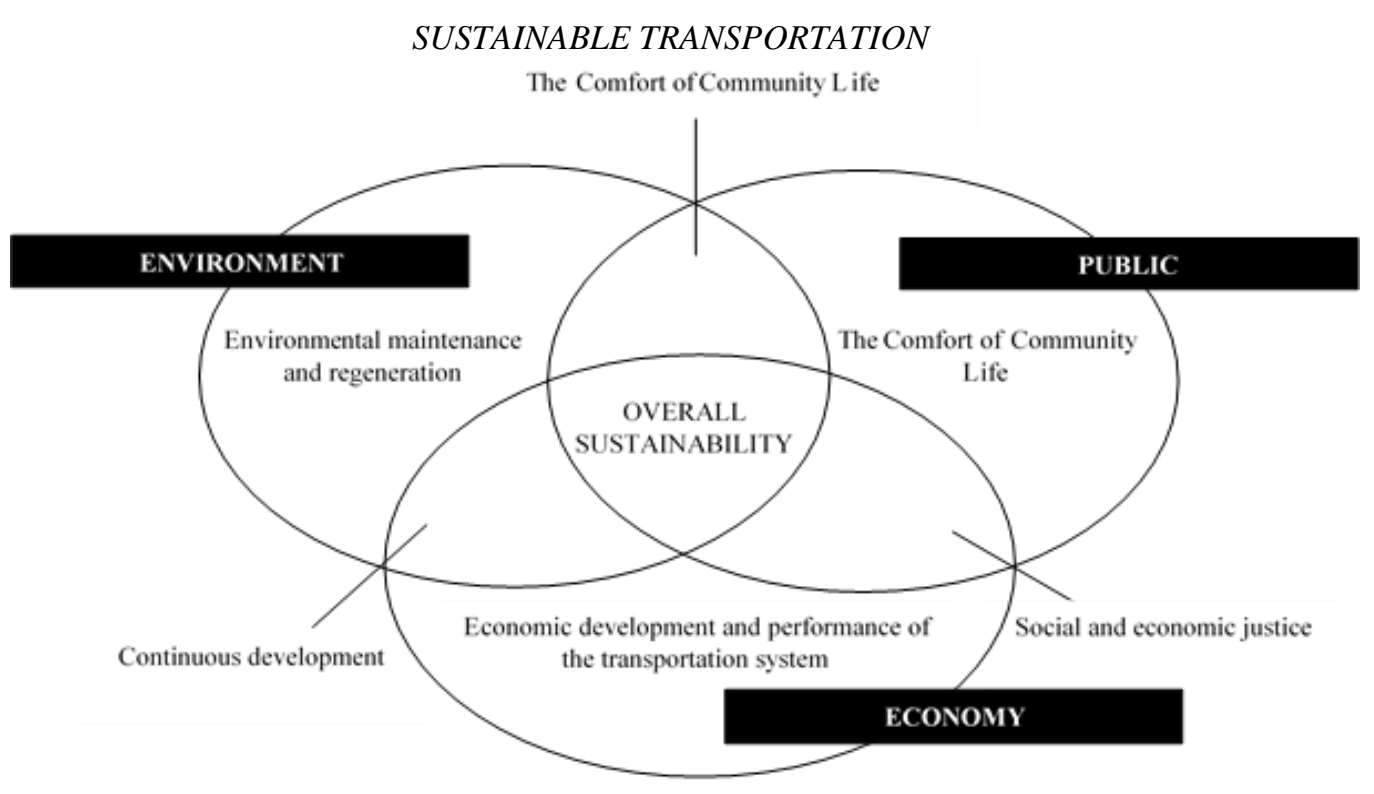

Fig.1. Interaction Between Elements in a Sustainable System [17]

Sustainable Transportation is a provision of base transportation access for community needs that provides a sense of security, ecosystem health, a choice of transportation modes that can support the economic cycle by minimizing public expenditure and minimizing land use that will cause traffic chaos. [18]. Suroboyo Bus tries to minimize the expenses incurred by the community at a relatively cheap cost of Rp. 3000,- whereas if we take other public transportation is Rp. 5000-6000, even when compared to using private vehicles, using the Suroboyo Bus is cheaper and more economical.

Meanwhile, the Center for Sustainable Development (1997) is a sustainable transportation system that provides safe access to the basic needs of every individual or community that is consistent with human health and ecosystems. Thus, this is what is meant by an ecologicallybased sustainable transportation system. The concern for ecology in Surabaya is how transportation provides life for living things such as ecosystems. When the number of transportation increases, pollution caused by the impact of exhaust gas emissions will affect the life of the ecosystem underneath. This is implemented by Suroboyo Bus by implementing a payment system that uses waste and to reduce environmental problems, it can also be in the form of character savings. By utilizing waste as a method of payment for Buses, it has helped to keep the life investment sustainable. 
Sustainable transportation is one aspect of overall sustainability that has three interconnected components, as shown in Figure 1, namely the environment, society, and the economy. In this interaction, transportation plays a vital role in the planning and providing a transportation system that must pay attention to these three aspects. These three aspects cannot be separated, and if, one is omitted, it will affect the realization of sustainable transportation. There are four pillars of sustainable transportation in urban areas [19]. The four pillars, namely:

1) Government or an effective agency as the realization of land use for integrated transportation.

2) The flow of the cost or funding mechanism for stable transportation to create efficient and fair funding. 3) Investments gave to sustainable transportation infrastructure. And 4) Support either from local government or support from the community.

Sustainable transportation is one of the agendas in sustainable development, which is a development process characterized by the fulfillment of the needs of today's society without having to sacrifice the fulfillment of future community needs. Sustainable development aims to equalize development between the current generation and future generations. According to Heal, there are two dimensions in the concept of sustainable development, namely time and interaction [20].

\section{Principles Towards Achieving Sustainable Transportation}

\section{Accessibility for anyone}

The main objective of providing a transportation system is to provide accessibility (convenience) for every user, whether human, goods, and services, at a fair, balanced, low cost, and with minimum negative impact. Suroboyo Bus provides accessibility for all residents of Surabaya without exception at Rp. 3000,- if we pay with cash or we can also pay with plastic waste.

\section{Social Justice for Everyone}

It often happens everywhere that transportation is always not prioritized for low-income groups. Because of their finances, they do not choose or do not use transportation modes in their livelihood. Social justice policies should provide public transport, pedestrians, and nonmotorized vehicles easily accessible for priority and have little impact. Suroboyo Bus strives to create social justice. Every passenger has the same rights, is entitled to the same and excellent service.

\section{Ecological Sustainability}

Too many motorized vehicles can damage the environment. The local impact of the transportation sector is air and noise pollution, which are mostly found in big cities in Asia. Suroboyo Bus is an effort to achieve sustainable transportation in the environment. A payment system that uses plastic waste can reduce environmental problems. The government will find it easier to collect household waste. This will also add value to the economic efficiency of the community because it does not cost a lot to be able to enjoy Suroboyo Bus services. Apart from that, the attention of the Suroboyo Bus, to the parks along the road or route that the Suroboyo Bus passes, must also get attention, in its operation, it must pay attention to the exhaust 
emissions caused by this transportation to the availability of green trees which reduce the carbon from the vehicle pollution. To keep the spread of air pollution that will be absorbed by humans.

\section{Health and safety}

Transportation has a significant impact on health and safety. Motorized vehicles contribute to $70 \%$ of air pollution in many places in major cities of the world including Surabaya. More than 500,000 people died every year, due to vehicle accidents, and more than 50 million people are seriously injured worldwide. In developing countries, more than $60 \%$ of accident victims are pedestrians and other road users. Safer trips were carried out in places that provide public transport facilities, pedestrians, and cyclists. The city of Surabaya has provided services with unique routes, where every road user has the same rights. The Surabaya city government has made efforts for equitable development to create national health and safety. Public transportation, which pays more attention to passenger comfort and safety, equipped with various facilities, mass transportation can be sustainable mass transportation to avoid congestion problems. Pedestrians are provided with pedestrian areas/paths equipped with safety and comfort facilities such as balls in the pedestrian area and instructions. Pathway for the disabled, and cyclists, it has a lane on the side of the highway. Every road user must have an attitude of belonging to each other, obey the rules that have been set, especially the rules in traffic, to maintain the safety and security of ourselves and those around us.

\section{Public participation and transparency}

In transportation planning, this is very necessary, to get a controlled transportation development direction. The existence of planning can be used as a guide for development. Planning becomes an excellent way to involve every community/group/institution affected by the planning. Public transparency and information disclosure to the public will prevent acts of corruption that will inevitably harm the community/group/institution. The transportation planning process must be carried out openly by involving related parties (stakeholders) so that its implementation can run optimally. In planning the Suroboyo Bus transportation, the government of the Transportation Service can cooperate with the Environmental Service in planning ecology-based transportation.

\section{Economical and cheap}

Transportation policies should lead to projects/programs that are inexpensive and can be used for the use of very expensive transportation (private cars). By limiting private vehicles and inhibiting their growth, cities will avoid having to build expensive road networks. Suroboyo Bus as mass transportation can be a barrier so that the personal concept does not improve. With a one-way low price, it can provide every passenger.

\section{Information and analysis}

An organization/agency must understand things related to priorities that must be done so that there are no mistakes in its implementation. They must be able to argue with the proposed policies submitted by the government. This is a form of public control over government policy. 
The government must also be willing to accept criticism and provide a forum for submitting complaints about the non-conformity of a policy.

\section{Advocacy}

The ability to advocate is needed in a sustainable transportation system. Sometimes the government doesn't listen to people's aspirations and only puts forward the wishes of investors. The provision of advocacy institutions such as NGOs is crucial in helping the government to gather public voices in increasing development participation.

\section{Capacity Building}

The formation of a joint commitment between decision-makers to change the planning paradigm to replace the mobility of private vehicles with public transportation is needed. If a commitment is carried out properly, then the application of Suroboyo Bus as sustainable mass transportation will be maintained.

Community organizations/groups must be prepared to increase the ability to convey their right to speak regarding developing transportation issues, must understand basic issues, and know-how to take the next steps. The decision-making process in determining the next steps must consider various related aspects.

\section{Networking}

Networking between organizations is needed actively so that the process of exchanging information becomes easier and cooperation between organizations can be done quickly and accurately. Through this network, new ideas, information, lessons from other places, and solidarity can be obtained to produce better goals for the entire organization to create innovations in the development of sustainable transportation. If Suroboyo Bus has a good network, then the development will not lack creative ideas in building it.

Efforts to create an ecologically-based sustainable transportation system have been made by the Surabaya city government. Many strategic efforts can be made to raise an ecologicallybased sustainable transportation system in the city of Surabaya, according to Rahardjo and Sakti Adjisasmita's solution [21], videlicet

\section{a. $\quad$ Creating a Comprehensive Urban Transport Policy}

Urban transportation policies include: First, a consolidated transportation policy, which is to make the most of the available transportation modes. The two coordinated transportation policies, namely each type of urban transportation means in carrying out its activities, providing the number and capacity that are placed in the routes it serves, determining transportation rates, determining routes, granting business licenses must be well-coordinated without prioritizing its interests. The three integrated transportation policies are the implementation of urban transportation service activities concerning transportation facilities and infrastructure which are implemented and managed in an integrated, comprehensive, fair, and comprehensive manner. Fourth, synchronized transportation policies, namely there is conformity or harmony between providing various means of transportation with the type, number, and size (transport capacity) 
and conformity in determining the routes it passes. The five balanced transportation policies are transportation services that are organized and directed to all parts of the urban area to meet the need for transportation services for people who are scattered in all parts of the urban area. The six harmonious transportation policies are a combination of consolidated, coordinated, integrated, synchronized, and balanced transportation.

\section{b. Perform Effective Traffic Management}

Carrying out effective traffic management, namely implementing traffic management to increase traffic smoothness and overcome traffic jams. Traffic management is very important especially to avoid congestion problems. Traffic management must also consider traffic-prone lanes and the density of the number of vehicles. In carrying out traffic management in various ways, such as differentiating pathways for pedestrians, motorbike riders, motorbikes, private cars, or buses.

\section{c. Operate Public Transport Facilities with Appropriate Capacity}

The provision of urban public transport transportation services involves the use of transportation facilities and the provision of transportation infrastructure. Various types of transport have different loading capacities, namely:

- Bus

The means of urban public transportation that are widely used in big cities is the type of bus. Buses have various sizes and different capacities. Large buses have a capacity of up to 5060 passengers, medium buses with 30-40 passengers, and small buses with 15-20 passengers.

- Microbus

Microbuses are small vehicles that operate to serve urban public transportation. The body area of a Microbus is half that of the bus, but the capacity of the Microbus is only 10 people or one-fifth (20\%) compared to large buses. Therefore, there was an idea to replace the microbus with a large bus that could carry more people. In order not to use many operating modes of transportation.

- Train

Railroad transportation services are carried out by a series of fan locomotives with several carriages, the number of which is adjusted to the needs, or the applicable regulations. Rail transport services have been organized to serve routes between cities.

- Monorail

The monorail is a railroad that uses railroad tracks built several meters (about 25-30 meters) above the ground, using many concrete piles that are managed by one another by concrete roads, on which a railroad is built. The railway is built several meters above ground level because of the limited land available at ground level so that it has been built above ground level. The monorail can be called an elevated train.

- Subway

Subway is railroad transportation below ground level. 
- Environmental transportation facilities

Residents living in residential areas need the availability of environmental transportation services. As houses in urban residential areas are relatively dense, small environmental public transportation facilities such as rickshaws are needed. This environmental transportation facility operates only to serve transportation within a residential area. The operational area of the transport has been determined. It is prohibited to operate on arterial roads and collector roads.

\section{d. Capacity Building of Transportation Infrastructure}

The smooth running of urban traffic requires the availability of sufficient road infrastructure so that mobility and accessibility are smooth and fast. Passengers and goods (cargo) are transported through transportation that moves on road infrastructure. Both form a transportation network consisting of a transportation infrastructure network and a transportation service network. Transportation infrastructure network consists of transportation connected by infrastructure such as roads. Transportation service networks are transportation means of travel that carry cargo between other transportation. Road construction for transportation must have sufficient capacity. The post-construction testing of infrastructure should be carried out to test the infrastructure's feasibility.

\section{Conclusions}

Sustainable Development is a development process marked by the fulfillment of the needs of today's society without sacrificing the fulfillment of future community needs so that equitable development between the current and future generations is fulfilled. It is necessary to develop a sustainable transportation system capable of providing access to the basic needs of every individual or society in a safe manner that is consistent with considering human health and ecosystems or what is called an ecologically sustainable transportation system. In its application, Suroboyo Bus is a type of transportation in the city of Surabaya as a sustainable mode of transportation that is ecologically based. However, its development still requires improvements, innovations that support it to turn it into a sustainable mode of transportation. Of course, in realizing this mission, it requires principles that must be considered in its implementation, namely including transportation, accessibility for whom, social justice for whom, a sustainable transportation system in the environment, paying attention to the health and safety of surrounding living things, can increase public participation and transparency, economic value and cheap, have clear information and analysis, promote community advocacy rights, pay attention to capacity building and networks. Besides, in realizing sustainable transportation, several strategies must be carried out in its achievement, namely creating a comprehensive urban transportation policy, carrying out effective traffic management, operating public transportation facilities with appropriate capacities, and developing transportation infrastructure. If the principles and strategies can be implemented and implemented properly, creating a sustainable transportation system will be achieved. 


\section{References}

[1] United Nations, "The speed of urbanization around the world," Population Bulletin of the United Nations, vol. 1, no. 8, pp. 16-33, 2018.

[2] A. Richter, M. O. Löwner, R. Ebendt, and M. Scholz, "Towards an integrated urban development considering novel intelligent transportation systems: Urban Development Considering Novel Transport," Technol. Forecast. Soc. Change, vol. 155, no. January, p. $119970,2020$.

[3] N. Aiura, "Planning on-Street loading-unloading Spaces Considering the Behaviour of Pickup-Delivery Vehicles," Plan. on-Street loading-unloading Spaces Considering Behav. Pick. Veh., vol. 6, pp. 2963-2974, 2005.

[4] A. Kumar and R. Anbanandam, "Development of social sustainability index for the freight transportation system,” J. Clean. Prod., vol. 210, pp. 77-92, 2019.

[5] D. Rockwood and D. Garmire, "A new transportation system for efficient and sustainable cities: Development of a next-generation variable speed moving walkway," Sustain. Cities Soc., vol. 14, no. 1, pp. 209-214, 2015.

[6] L. Wang, K. Wang, J. Zhang, D. Zhang, X. Wu, and L. Zhang, "Multiple objectiveoriented land supply for sustainable transportation: A perspective from industrial dependence, dominance, and restrictions of 127 cities in the Yangtze River Economic Belt of China," Land use policy, vol. 99, no. August, p. 105069, 2020.

[7] D. G. Williams, F. Spotswood, G. Parkhurst, and T. Chatterton, "Practice ecology of sustainable travel: The importance of institutional policy-making processes beyond the traveler," Transp. Res. Part F Traffic Psychol. Behav., vol. 62, pp. 740-756, 2019.

[8] U. Illahi and M. S. Mir, "Development of indices for the sustainability of transportation systems: A review of the state-of-the-art," Ecol. Indic., vol. 118, no. October 2019, p. $106760,2020$.

[9] S. Hedborg, P. E. Eriksson, and T. K. Gustavsson, "Organisational routines in multiproject contexts: Coordinating in an urban development project ecology," Int. J. Proj. Manag., no. January 2020.

[10] A. Pandit et al., "Infrastructure ecology: an evolving paradigm for sustainable urban development," J. Clean. Prod., vol. 163, pp. S19-S27, 2017.

[11] B. Surabaya, "Surabaya Dalam Angka 2020," Surabaya: CV. Azka Puta Pratama, 2020, p. 368.

[12] B. Susantoro and D. Parikesit, “1-2-3 Langkah: Langkah Kecil yang Kita Lakukan Menuju Transportasi yang Berkelanjutan,” Indonesian Transportation Magazine, Jakarta, pp. 8995, 2004.

[13] A. Ramadhiani, "Ini 10 Kota Termacet di Indonesia," Kompas.com, 2018. [Online]. Available: https://properti.kompas.com/read/2018/02/25/182046621/ini-10-kotatermacet-di-indonesia?page=all\#. [Accessed: 09-Oct-2020].

[14] N. Mueller et al., "Urban and transport planning related exposures and mortality: A health impact assessment for cities," Environ. Health Perspect., vol. 125, no. 1, pp. 89-96, 2017.

[15] R. Eddington, The Eddington transport study : main report: transport's role in sustaining the UK's productivity and competitiveness, no. December. 2006.

[16] L. Schipper, "Sustainable urban transport in the 21st century: A new agenda," Transp. Res. Rec., no. 1792, pp. 12-19, 2002.

[17] T. Klarin, "The Concept of Sustainable Development: From its Beginning to the Contemporary Issues," Zagreb Int. Rev. Econ. Bus., vol. 21, no. 1, pp. 67-94, 2018. 
[18] E. Holden, K. Linnerud, and D. Banister, "Sustainable passenger transport: Back to Brundtland," Transp. Res. Part A Policy Pract., vol. 54, pp. 67-77, 2013.

[19] D. Gusnita, "Green Transport: Transportasi Ramah Lingkungan Dan Kontribusinya Dalam Mengurangi Polusi Udara," Ber. Dirgant., vol. 11, no. 2, pp. 66-71, 2010.

[20] I. W. Suweda, "Penataan Ruang Perkotaan Yang Bekelanjutan, Berdaya Saing dan Berotonomi (Suatu Tinjauan Pustaka),” J. Ilm. Tek. Sipil, vol. 15, no. 2, pp. 113-122, 2011.

[21] Rahardjo and S. A. Adisasmita, Manajemen transportasi darat: mengatasi kemacetan lalu lintas di kota besar (Jakarta). Jakarta: Graha Ilmu, 2011. 